\title{
THE NATURE OF LAW AND REASONS FOR ACTION
}

\author{
Brian H. BIX ${ }^{1}$
}

\section{Resumen:}

Si una norma jurídica nos dice que hagamos algo, ¿acaso por ese solo hecho tenemos una razón para hacerlo? Esta sigue siendo una de las preguntas más básicas para la reflexión jurídica, tanto teórica como práctica. Se trata de una cuestión fundamental que muchos teóricos importantes del derecho han discutido; aunque el tópico sigue estando muy pobremente entendido. No obstante que recientemente muchos teóricos positivistas han buscado "explicar la normatividad", este es probablemente un proyecto inconsistente con los compromisos básicos del positivismo jurídico y, en cualquier caso, totalmente innecesario. Siguiendo las ideas de M. B. E. Smith y David Enoch, este artículo subraya que el derecho no siempre (o no "esencial" o paradigmáticamente) ofrece razones para la acción, y cuando es el caso que ofrece razones para la acción lo hace de una manera irrelevante.

Palabras clave:

Normatividad, filosofia moral, positivismo jurídico, teoría jurídica, razones para la acción.

Abstract:

If a legal rule tells us to do something, do we thereby have a reason to do it? This remains one of the most basic questions for theoretical and practi-

1 Frederick W. Thomas Professor of Law and Philosophy, University of Minnesota. 
BRIAN H. BIX

cal reflection on law. It is a foundational question, which many prominent contemporary theorists have discussed, yet the topic remains poorly understood. While many legal positivists have recently sought to "explain normativity", this is likely a project inconsistent with the basic commitments of legal positivism, and, in any event, thoroughly unnecessary. Following ides of M. B. E. Smith and David Enoch, this article emphasizes that law does not always (or "essentially" or paradigmatically) give reasons for action, and when it does give us reasons for action, it does so in unremarkable ways.

\section{Keywords:}

Normativity, Moral Philosophy, Legal Positivism, Legal Theory, Reasons for Action. 
SUmmaRY: Introduction. I. Reasons for Action. II. Law's Reasons. III. Legal Positivism and Explaining Normativity. IV. Law, Promises, and Plans: Obligations Out of Nothing? V. Reasons For Action - Revisited. VI. Conclusion.

\section{INTRODUCTION}

If a legal rule tells us to do something, do we thereby have a reason to do it? This remains one of the most basic questions for theoretical and practical reflection on law. It is a foundational question, which many prominent contemporary theorists have discussed, yet, I would urge, the topic remains poorly understood.

In this article, I will reflect on some current debates about the nature of law and reasons for action. Part I gives a brief overview of the idea of "reasons for action" and the role of that concept in practical reasoning and the analysis of normativity. Part II introduces the topic or issue of normativity in law. Part III focuses on recent efforts by some legal positivists to, as they label the project, "explain normativity". Part IV looks at proposed solutions that seemingly allow individuals or collectives to create reasons for action for themselves: a topic that is prominent in the analysis of promises, but which Scott Shapiro has recently raised for law through the idea of social planning. Finally, Part $\mathrm{V}$ reconsiders the problem of law and reasons for action, using the work of David Enoch.

\section{REASONS FOR ACTION}

From Aristotle to the present, discussions on moral, political and legal philosophy have been helpfully analyzed in terms of practical reasoning. ${ }^{2}$ Practical reasoning asks what

2 In contemporary English-language discussions a major impetus in this form of analysis came from Joseph Raz's Practical Reason and Norms (Hutchinson, 1975; 2nd ed., Princeton, 1990). 
reasons we have for action (the contrast is with theoretical reasoning, the reasons we have for belief). Contemporary discussions about the interrelated questions about the normativity of law, ${ }^{3}$ the authority of law, the moral obligation to obey the law, and the relationship generally between law and morality, all tend to be analyzed in terms of reasons for action. I will follow this (generally wise and helpful) trend of discussing these matters in terms of reasons for action, and will explore the connections between the different concepts in passing throughout the paper.

Does the law give us reasons for action? Lon Fuller, writing in the course of his famous 1958 debate with H. L. A. Hart, and in a critical summary of the legal positivists' views about the dilemma about obeying the law, summarized what he took the legal positivist position to be:

"On the one hand, we have an amoral datum called law, which has the peculiar quality of creating a moral duty to obey it. On the other hand, we have a moral duty to do what we think is right and decent." 4

Fuller here touches on a seeming mystery that has perplexed theorists for some time -and not just legal positivists, though this is the category of theorists thought to be in most difficulty given their other theoretical assumptions and assertions. The mystery is that if law is a social practice and social institution - something capable of being described in empirical terms, how is it that it can generate legal norms, statements of what ought to be done? In part, this is a question about the division (usually attributed to David Hume, but, in any event, generally accepted

3 "Norm" and "normativity" have their own complex history, as outlines in Stanley L. Paulson, “A 'Justified Normativity’ Thesis in Hans Kelsen's Pure Theory of Law? Rejoinders to Joseph Raz and Robert Alexy", in Matthias Klatt (ed.), Institutionalized Reason: The Jurisprudence of Robert Alexy (forthcoming, Oxford, 2011).

4 Lon L. Fuller, "Positivism and Fidelity to Law - A Reply to Professor Hart," 71 Harvard Law Review , 630, 656 (1958). 
by theorists) that one cannot derive an "ought" statement as a conclusion if all of one's premises are "is" statements.

Of course, we usually have reasons, and good reasons, to do what the law tells us to do. Most prominently, perhaps, if we act contrary to the law's orders, and our actions are discovered by officials, we are subject to civil or criminal punishment. These are simple prudential reasons to do what the law says, due to fear of sanctions, but that is not the usual focus of theorists who talk about the law and reasons for action.

In part, this is because it is claimed that law is, or at least can be, something distinctly different from "the gunman situation writ large."5 To be sure, some legal systems are understood by those subject to them as little more than gangsters or tyrants with coercive force behind them, where obedience occurs only because of the fear of reprisal, and stops whenever the fear stops. However, most legal systems offer themselves as something different than mere orders backed by force - whether that is how they are perceived by their subjects or not. They present themselves as creating obligations, as stating what ought to be done (whether or not sanctions are imposed for violations). Joseph Raz claims that all legal systems, by their nature as legal systems, claim the status as practical authorities -as giving us preemptive or exclusionary reasons for action. ${ }^{6}$ However, one need not agree with Raz's controversial claim about what is essential to law (or Robert Alexy's comparable "Correctness Thesis"7) to assent to the point basic for our purposes: that legal systems - generally, if not universally or essentially- purport to give us "obligations" for action, not just coercive motivations for action.

5 H. L. A. Hart, "Positivism and the Separation of Law and Morals," 71 Harvard Law Review, 593, 603 (1958).

6 E.g., Joseph Raz, Ethics in the Public Domain (Oxford, 1994), pp. 194-221, especially pp. 195-204.

7 Robert Alexy, The Argument from Injustice: A Reply to Legal Positivism (Stanley L. Paulson \& Bonnie Litschewski Paulson, trans., Oxford, 2002), pp. 76-81. 
There is another, generally uninteresting sense in which we usually have reason to do what the law tells us to do. In every, or nearly every legal system, legal rules tell us not to rob, murder, or to drive 200 kilometers an hour on the highway, and most of us would agree that we in fact have good reasons not to rob, murder, or drive 200 kilometers an hour on the highway.

However, we had reasons to do these things which the law tells us to do - and to avoid doing these things that the law prohibits - long before the law spoke on the matter, and our reasons are independent of the law. Morality (and perhaps mere prudence) impose these constraints on us. That law usually tracks morality is a good thing, but for the purpose of determining whether the law gives us reasons for action, the overlap of law and morality only tends to confuse us.

One can believe, of course, that morality gives one a reason, say, not to kill, but that law gives an additional reason. As M. B. E. Smith points out, to understand the significance in areas where law and morality overlap, one should think of situations where an action is already wrong, but one thinks it even worse when one finds out that it is also illegal. ${ }^{8}$ In the United States, many bankers and investors defrauded consumers of large amounts of money, in some cases retirement funds those consumers had been saving their entire lives. Because of complicated statutes and regulations, it remains to this day uncertain whether what these bankers and investors did was illegal under the complex United States legal rules and regulations. However, my intuition, at least, is that discovering that the actions were or were not illegal will not much affect my views, or most people's views, about how immoral those acts of fraud were.

Smith's other example is reporting a third person's actions: if you tell a friend that what this person did was "illegal", but refuse to report further on the nature of the ac-

8 See M. B. E. Smith, "Is There a Prima Facie Obligation to Obey the Law?", 82 Yale Law Journal 950-976, at 969-973 (1973). 
tion, the chances are good that the other person will withhold moral judgment until they know more. We tend not to give significant moral weight to the mere fact, without more, that an action was consistent with or contrary to what the law prescribed.

\section{LAW'S REASONS}

While modern theorists - ranging from Hans Kelsen to $\mathrm{H}$. L. A. Hart to John Finnis to Joseph Raz - agree that it is basic to law's nature that it is "normative," there seems to be surprisingly little agreement on what is (or what could be) meant by that.

H. L. A. Hart seemed to believe that the legal "ought" -the duties and rights of law- was different in kind from the moral "ought", even though the terminology was the same. ${ }^{9}$ Hart in this sense sought a conceptual space to allow for law's normativity, while resisting the notion that the legal "ought" was equivalent to, or in some way derived from, the moral "ought."

Hart's approach of holding legal normativity as a distinct form of normativity has the benefit of giving a clear and simple explanation for the commonplace observation: "yes, you have a legal obligation to do $\mathrm{X}$, but I do not think you have a moral obligation to do so - in fact, you might have a moral obligation to violate the law that requires X." The difficulty with the approach is that there is an unsettled and unpersuasive feel to the view that there is a kind of (legal) normativity that uses the same terminology as moral normativity, parallels its claims, and justifies actions or forebearances in the circumstances where morality would normally operate (e.g., punishing deviation form prescriptions, limiting liberty, etc.), but is in fact entirely different. ${ }^{10}$

9 H. L. A. Hart, Essays on Bentham (Oxford, 1982), pp. 127-161; see also Joseph Raz, "Hart on Moral Rights and Legal Duties," Oxford Journal of Legal Studies, vol. 4 (1984), pp. 123-131.

10 For a good summary and critique of Hart's view here, see Scott Shapiro, Legality (Harvard, 2011), pp. 101-102, 110-115. 
Hart also focused on normativity in his discussion of the "internal point of view,"11 which has been accepted by theorists as far apart methodologically as John Finnis and Joseph Raz. ${ }^{12}$ In very rough terms, this approach argued (or, at times, merely assumed) that theories of law would be better to the extent that they accounted for the perspective of those citizens who viewed the law as giving them reasons for action. This approach to legal theory reflects the general "hermeneutic" or "Verstehen" approach to the social sciences: a view that knowledge of social institutions is distinctly different from knowledge in the physical sciences, and that a primary focus of theorizing is and should be awareness of the motivations and purposes of participants, emphasizing participants' understanding, not merely their behavior.

However, this does create an awkwardness, especially for legal positivist theorists who deny that law in general, or particular legal norms, carry any necessary moral value. The internal point of view is not quite a presumption in favor of law's creating reasons for action, but it certainly gives that view favored status. For this reason, some theorists (most prominently, Frederick Schauer) have argued for a return to a legal positivism that was not grounded on a hermeneutic approach, not built around any internal point of view. ${ }^{13}$

Hans Kelsen's approach converges with Hart's, at least on the emphasis both give to the normativity of law. Kelsen argued that individuals sometimes viewed factual circumstances in a normative way: that this could happen with morality, religion, law, and many other sorts of normative

11 H. L. A. Hart, The Concept of Law (rev. ed., Oxford: Clarendon Press, 1994) at 56-57, 84-91.

12 John Finnis, Natural Law and Natural Rights (Oxford: Clarendon Press, 1980) at 3-18; Joseph Raz, Practical Reason and Norms (Princeton: Princeton University Press, 1990) at 170-177.

13 See, e.g., Frederick Schauer, "Positivism Through Thick and Thin," in Analyzing Law: New Essays in Legal Theory (Brian Bix, ed., Oxford: Oxford University Press, 1998), pp. 65-78. 
ways of seeing or experiencing. ${ }^{14}$ One need not accept the normative view of government orders: one can see the actions of officials as the anarchist or rebel does, as the commands of powerful people one would be prudent to obey, but nothing more. These skeptics see law in a purely empirical way - descriptions of what officials have done, and predictions of what might happen if one acted contrary to their wishes. One could bring the same skeptical, cynical and empirical view towards the normative systems of religions, conventional views of morality, or etiquette, not believing that any duties were created by those systems, and complying outwardly only to the extent that one believed that it served one's purposes to do so.

Thus, for Kelsen, one either speaks of the acts of legal officials in normative terms (one ought to do this because the law so directs) or one does not, just as one either speaks of the rules of a religious system normatively or one does not. To speak of a legal system —or a religious system- normatively is implicitly to endorse the foundational axiom of that normative system (which Kelsen called the Grundnorm, the Basic Norm). In the case of a religion, the foundational axiom might well be something like "you ought to do as the omniscient, omnipotent Creator Being orders", while for a legal system, it might be more like "one ought to act according to the norms authorized by the historically first constitution". 15

Recall again our basic question: Does the law give us reasons for action? One tentative answer suggested by these great legal theorists is that perhaps it does, but only if one brings the right attitude to law —taking an internal point of

14 On Kelsen's views generally, see Hans Kelsen, The Pure Theory of Law (Max Knight trans., University of California, 1967); Hans Kelsen, Introduction to the Problem of Legal Theory (Bonnie Litschewski Paulson \& Stanley L. Paulson, trans., Oxford, 1992). On Kelsen and normativity, see Paulson, "A 'Justified Normativity' Thesis in Hans Kelsen's Pure Theory of Law?, supra note 3.

15 This short summary elides some significant details that are not crucial for present purposes. The picture for Kelsen is, at closer examination, both intricate and contested. See Paulson, “A 'Justified Normativity' Thesis in Hans Kelsen's Pure Theory of Law?, supra note 3. 
view, or viewing the legal system normatively. And both theorists indicated that the reasons given by law might be different both from purely prudential reasons and different from the reasons given by morality.

\section{LEgAL Positivism AND EXPLAINING NoRMATIVITY}

As noted, a number of prominent legal positivists in recent years have taken it as an urgent project -and have taking it as their project - to "explain law's normativity." By that, they report that what needs to be explained is the way that law gives us reasons for action. As mentioned, the discussion is in related and interlocking concepts: the authority of law, the normativity of law, and the way that legal rules give citizens reasons for action. ${ }^{16}$ There is always something a little ironic when legal positivists try to explain the normativity of law, for it is generally considered to be foundational to that approach to law that it denies any necessary moral content to legal systems in general or valid legal norms in particular. ${ }^{17}$

There are further complications, some of which can be seen through the topic of the obligation to obey the law. ${ }^{18}$ In the 1960 s and early 1970 s, both conservative and liberal political and legal scholars seemed to assume that there was a presumptive moral obligation to obey the law, at least within generally just legal systems (that view goes back much farther historically, with theorists as diverse as Socrates, John Locke, Jeremy Bentham, and Immanuel Kant asserting similar positions of a moral obligation to obey, with most of these theorists extending that obligation even

16 See, e.g., Jules L. Coleman \& Brian Leiter, "Legal Positivism," in Dennis Patterson (ed.), A Companion to Philosophy of Law and Legal Theory (2nd ed., Wiley-Blackwell, 2010), pp. 228-248, at 228-31, 233-35.

17 See Brian Bix, "Jules Coleman, Legal Positivism, and Legal Authority," 16 QLR [Quinnipiac Law Review] 241 (1996).

18 One of the best overviews of the debate regarding the moral obligation to obey the law remains M. B. E. Smith, "Is There a Prima Facie Obligation to Obey the Law?", supra note 8 , from which parts of the following discussion are adapted. 
to some unjust legal rules). ${ }^{19}$ H. L. A. Hart famously argued that we had an obligation - not so much to the state, but to our fellow citizens - to obey the law, based on mutuality of sacrifice in a joint project, ${ }^{20}$ while other theorists argued for such an obligation based on the more conventional arguments of consent, gratitude or consequentialism.

Subsequently, M. B. E. Smith and Joseph Raz (among many others) have put forward the argument that there is no general moral obligation to obey the law, though there may be moral obligations to obey particular laws (the extent of moral obligation varying both from law to law, and from person to person), with moral duties being grounded (if at all) based on considerations like salience in coordination, where coordination is needed to solve a social problem, and relative expertise. ${ }^{21} \mathrm{We}$ have reasons to defer to the law on some matters, but not on all matters, and (therefore) not merely because the law so declares, without any consideration of the topic and content of the prescription.

Importantly, for the modern skeptics of (opponents of) a general moral obligation to obey the law, the traditional equation of state legitimacy and citizen obligation is severed. The traditional view (espouses, e.g., by the great social contract theorists, like Thomas Hobbes, John Locke, and Immanuel Kant) was that if the government acts legitimately, then citizens have a moral obligation to obey. Contemporary theorists deny this. However, those who deny that citizens have a general presumptive moral obligation to obey the law are not thereby claiming that government never has the moral right to act, or that government never has the right to coerce citizens, punish for disobedience to

19 As a presumptive moral obligation, it can be overridden where there are sufficiently strong moral reasons for disobedience. Perhaps only Thomas Hobbes would argue for a moral obligation to obey even a substantially unjust law.

20 H. L. A. Hart, "Are There Any Natural Rights", 64 Philosophical Review 185 (1955). John Rawls argued for a similar position around the same time. John Rawls, "Legal Obligation and the Duty of Fair Play, in Law and Philosophy" 3-18 (Sidney Hook ed., NYU Press, 1964).

21 See Smith, "Is There a Prima Facie Obligation to Obey the Law?", supra note 8; Raz, Ethics in the Public Domain, supra note 6, at 325-338. 
official rules, or restrict liberty in other ways. ${ }^{22}$ For contemporary theorists, the moral prescriptions for government and the moral prescriptions for citizens are simply distinct, if overlapping (at least in the negative sense that where the government lacks legitimacy in its promulgation of some law, it is unlikely that individual citizens will have a moral obligation to obey that law). Reasons for action for governments and government officials are established by a different analysis than reasons for action for citizens.

\section{LAW, Promises, ANd Plans: \\ OBLIGATIONS OUT OF NOTHING?}

As earlier discussed, one view of the problem of whether law gives us reasons for action is structured as follows: law as a social institution entails certain facts about the world, and, especially if one rejects a certain kind of natural law theory, one cannot assume that law derives directly from morality. How can it be that the set of facts that is law can entail obligations, obligations in the world. If one's premises are empirical rather than normative, it does appear that one is either violating the (Humean) division of "is" and "ought" or that one has somehow conjured up a reason for action out of nowhere.

There are theorists who argue that we sometimes can create moral reasons - reasons for action- out of nothing, at least the normative "nothing" of purely descriptive facts.

One such example, seemingly far from the jurisprudential context, is promising. To some commentators, promising seems like a magic trick: one can create moral reasons for action (for oneself) just by trying to do so - just by saying some special words. It does not seem like something as special or as distinctive as moral obligations should be as easily produced. Some theorists respond to this objection by seeing promising as a social convention, established by

22 See Joseph Raz, The Morality of Freedom (Oxford, 1986), pp. 23-28. 
society for the general benefit, which individuals then participate in. ${ }^{23}$

Some modern legal theorists have argued for a similar sort of bootstrapping with law. The first set of such efforts involved seeing the Hartian rule of recognition as a coordination convention: ${ }^{24}$ officials, the argument went, had reasons to follow the rule of recognition because other officials were following that set of rules, there were good reasons to have a system with an agreed ultimate rule, even if that agreed ultimate rule were not otherwise the optimal one. ${ }^{25}$ There are problems with this conventional analysis of the rule of recognition and how it gives officials (or anyone else) reasons for action, for a legal system's rule of recognition seems quite different from paradigmatic cases of conventions - like cars should drive on the left side of the road or the right side. It does matter which ultimate rule of recognition one chooses (unlike which side of the road one drives), and it is far from obvious that officials should or would prefer a consensus on a bad rule to fighting for their own view of a better rule. ${ }^{26}$

Most recently, Scott Shapiro has argued for a different sort of jurisprudential reason-from-nothing, arguing that law can create reasons for action because law is a shared social plan (and legal norms are plans or "plan-like norms"). ${ }^{27}$ There is an obvious parallel with promises. If I promise to do something - and not merely "intend" to do it - I have a reason to do that action, a moral or quasimoral reason that I did not have before. Similarly, Scott Fried.

23 This is the view, to varying degrees, of David Hume, Joseph Raz, and Charles

24 On conventions and their reason-giving properties, see, e.g., David Lewis, Convention: A Philosophical Study (Harvard, 1969).

25 See, e.g., Gerald J. Postema, "Coordination and Convention at the Foundations of Law," 11 Journal of Legal Studies 165-203 (1982).

26 E.g., Shapiro, Legality, supra note 10, at 105-110.

27 See Shapiro, Legality, supra note 10. 
Shapiro ${ }^{28}$ argues that when we make a plan - either individuals making a plan for preparing dinner, or a group making a shared plan to institute a legal system- we have thereby created a reason we did not have before, to do as our plan dictates. Shapiro notes that in extreme circumstances, we would be rationally justified in changing or abandoning our individual or shared plan, but the presumption is to follow through with the plan. More controversially, Shapiro goes on to argue that a legal system is a kind of master plan, and enacted laws are themselves plans or plan-like norms. His basic argument is that viewing law as a kind of shared social planning allows us to understand (and justify) how law creates reasons for action.

Nonetheless, the basic underlying notion, that one can create moral reasons for action from nothing - whether via promises, conventions, or plans - remains controversial. And, in the end, such an approach may be unnecessary.

\section{REAsons For Action - REVISITED}

David Enoch, in a recent work, has worked as much to "deflate" the problem of law's reason-giving as to resolve it. ${ }^{29}$ His basic point is that there is nothing that remarkable about the giving of reasons for action.

Enoch grounds his work on clarifications of the different ways of giving reasons for action, and how distinguishing among types of ways of giving reasons for action can help our analysis of the legal case. First, someone may call our attention to a reason for action that already applies to us (what Enoch calls "epistemic" reason-giving). For example, before I do something rash, you might remind me of my obligation to be a good role model to my child or to my students. This reason was always present, and your reminding

28 Here he is (as he notes) following the work of the philosopher Michael Bratman and others.

29 David Enoch, "Reason-Giving and the Law," in Oxford Studies in the Philosophy of Law, vol. 1 (Leslie Green \& Brian Leiter eds., 2011), pp. 1-38. 
me did not in any way change the reasons for action that apply to me, but you effectively helped me to (re-)discover those already-existing reasons.

Second, certain changes in non-normative facts can trigger reasons that already apply to us. Thus, the rise in the cost of some product can warrant our buying less of it, where the changed price is a non-normative fact, triggering our existing ("conditional") reason to put limits on how much we spend. It is not that the fact "created" the reason, in some way that violates the "is" / "ought" division; rather, the fact is just part of the premise, along with an "ought" premise (e.g., never spend so much that one does not have enough left to pay the rent) that was already there, but had not been invoked until the new fact was introduced.

Enoch contrasts those two forms of reason-giving, epistemic and triggering, with a possible third kind of reason-giving, which he calls "robust reason-giving." Under this possible third kind, someone's statements or actions do not simply remind us of existing reasons, or trigger the effect of existing reasons, but creates reasons that were not there before. Many people believe (or assume) that requests and commands are "robust reasons" of this sort, and others ascribe the same status to promises or plans.

However, when Enoch investigated likely examples of robust reason-giving - like a request or a divine commandthey seemed to be merely examples of triggering existing conditional reasons people already had (e.g., "if a friend asks you to help her on a small task, you should do so"). Nonetheless, Enoch argued, robust reason-giving might yet be considered a special sub-category of triggering reasons, with the following characteristics: in an interaction between A \& B, A must have specific intentions to create reasons for $B$, and $B$ must recognize and be responding to those intentions. ${ }^{30}$

In the course of considering whether law gives us "robust reasons," Enoch notes that we must distinguish normative

30 Id. at 5-14. 
reasons from motivating reasons. ${ }^{31}$ Motivating reasons are part of a certain kind of causal explanation: it is explains why we decided to do what we did - a psychological or historical claim. Normative reasons are reasons that justify an action, that make it the right or rational thing to do. As noted earlier, when we are concerned philosophically with whether law gives us reasons for action, our focus is properly on the normative reasons, not motivating reasons.

After all this stage-setting, Enoch comes to a radically modest conclusion - I say "radically" modest, because it is in contrast to the stronger conclusions that many other theorists have reached, or even merely assumed. He sees no basis for assuming that law always (or "necessarily") gives reasons for action (other than "legal reasons for action"). He views the notion that law would always give reasons for action as "clearly false." 32 Indeed, such a view does seem contrary to most people's basic intuitions. We do not think that legal rules always direct (the most) moral action, even if we constrict our focus to the legal rules of generally just legal systems. And most of us have no trouble coming up with examples of legal systems - even "generally just" legal systems- issuing rules that were in some way contrary to what morality required.

At most, Enoch concludes, law sometimes gives reasons for action, as would be expected from normal triggering reasons - "the giving of the reason amounts to a manipulation of the non-normative circumstances in a way that triggers a preexisting conditional reason."33

In summary, Enoch shows that there is no great mystery to law's reason-giving. Law does not give us reasons in any special or robust way that requires additional explanation. Law gives us reasons the way that most of our reasons are given: as non-normative "triggers" to reasons for action that were always already there.

\footnotetext{
31 Id. at 15 .

32 Id. at 20.

33 Id. at 26.
} 


\section{CONCLUSION}

I expressed earlier my suspicion that trying to "explain normativity" is not something that legal positivists need to do or should be doing. And as emphasized by theorists like M. B. E. Smith and David Enoch, explaining how law (always) gives reasons for action may be a misguided quest as well, not because of any mis-match with the dogma of some theory, but because law does not always (or "essentially" or paradigmatically) give reasons for action, and when it does give us reasons for action, it does so in unremarkable ways. As Ludwig Wittgenstein frequently argued, sometimes philosophy is difficult because we are trying to do things that are both impossible and unnecessary. 